\title{
The egg-laying behaviours of the gastropod mollusks
}

\begin{abstract}
The gastropods are commonly known as snails and slugs. They are a large taxonomic class within the phylum Mollusca. The cerebral neurosecretory caudodorsal cells (CDCS) of the fresh water pulmonate Lymnaea control egg laying, an event that involves a pattern of stereotyped behavior. The CDCS synthesize and release multiple peptides, among which is the ovulation hormone (CDCS). It is thought that each peptide controls a specific aspect of the processes involved in egg laying. Dopamine is commonly found in the molluscan central nervous system (CNS). In some gastropods, dopamine has been implicated in the regulation of egg laying behavior that stimulates protein secretion from albumen gland. The albumen gland in pulmonate snails is an accessory gland of the female reproductive tract. It synthesizes and secretes perivitelline fluid (PVF), which is composed mainly of proteins and polysaccharides
\end{abstract}

Volume 4 Issue 2 - 2018

\author{
Arun Kumar Srivastava,' Vinay Kumar Singh² \\ 'Department of Zoology, Shri Guru Goraksha Nath Degree \\ College, India \\ ${ }^{2}$ Department of Zoology, DDU Gorakhpur University, India
}

Correspondence: Arun Kumar Srivastava, Department of Zoology, Shri Guru Goraksha Nath Degree College, Maharajganj-273I5I, UP, India, Tel +9 I-97922507 I O, Email aksgkp5@gmail.com

Received: January 24, 2018 | Published: March 07, 2018

Keywords: CDCS, dopamine, peptides, $\mathrm{CDCH}$

Abbreviations: CDCS, caudodorsal cells; CNS, central nervous system; PVF, perivitelline fluid; $\mathrm{CDCH}$, caudodorsal cell hormone

\section{Introduction}

Mollusca is the largest marine, phylum about $23 \%$ of all the named marine organism. ${ }^{1}$ The gastropods, more commonly known as snails and slugs, are a large taxonomic class within the phylum Mollusca according for $80 \%$ of total mollusca. ${ }^{2}$ Fresh water gastropods are divided in to two subclasses, Prosobranchia and Pulmonata. Most of the species associated as intermediate hosts of helminthes parasite. ${ }^{3,4}$ Planorbidae and Limnaedae colonized in freshwater habitat because they have broad physiological and ecological concepts. The anatomy, behavior, feeding, and reproductive adaptations of gastropods vary significantly from one clade or group to another. Therefore, it is difficult to state many generalities for all gastropods. Observation showed that the snail population and frequency of infection greatly varies from place to place and seasonally. The snail has to respond against environmental change. The first review of reproduction in fresh water pulmonates are pointed by Duncan ${ }^{5}$ later on Geraets \& Joose. ${ }^{6}$ Among pulmonates hermaphroditism is universal and almost universal among ophisthobranche gastropods but rare in all other gastropods. ${ }^{7}$ The hermaphroditism means adult has both female and male functioning system but it is not necessary that individual engages both sexual function in any single mating. ${ }^{7}$ Aquatic gastropods generally deposite their eggs in gelatinous capsule that are attached to surface or aquatic plant leaves. The self fertilization in pulmonates was first noted by. ${ }^{8}$ The gonad is called ovotestis/ gonadal tissue and sperm are passed through via duct in to vesicular seminal. The release of ova from the gonads is controlled by hormone at least in the ophisthobranch and basometophoran pulmonates and may be land snail. ${ }^{7}$ The endocrine gland secrete these hormone have been characterized in Lymnaea and Aplysia. ${ }^{7}$ The caudodorsal cells are present in cerebral ganglion and release two ovulation hormone. Abiotic factors increases the rate of reproductive capacity. ${ }^{9}$ Srivastava et al. ${ }^{10}$ reported significant positive correlation between acetyl cholinesterase and egg laying in Lymnaea acuminata a fresh water pulmonates. The aim of the present review is demonstrate the role CDCs cells, their structure and mechanism involve in reproduction behavior of pulmonates.

\section{Role of caudo dorsal cells (CDCs)}

Roubos et al. ${ }^{11}$ reported that in gastropod the peptidergic neurons controlling egg-laying produce multiple peptides which are cleaved from a common precursor. Before egg laying, these cells produce a discharge of action potentials during which the peptides are released and egg-laying behaviour is initiated. ${ }^{12}$ Hermann et al. ${ }^{13}$ reported that in Lymnaea stagnalis the neuroendocrine cells controlling egglaying are the caudodorsal cells (CDCs) which is a group of about 100 electrotonically coupled neurones, located in the cerebral ganglia. These cells have axons that form a neuro haemal area in the cerebral commissure and from this area, CDC peptides are released into the blood during the electrical CDC discharge. ${ }^{14}$ The CDCs exhibit three states of excitability, resting, active and inhibited each with distinct electrophysiological characteristics. Transitions between these states can occur spontaneously or can be induced experimentally. ${ }^{13}$ When the CDCs are in the resting state, a train of depolarizing current pulses elicits an after discharge, the active state. From this active state, the cells enter the inhibited state. ${ }^{15}$ The ability to generate discharges is positively correlated with the amplitude of the depolarizing after potential that is induced by a short train of depolarizing current pulses. ${ }^{16}$ In the isolated central nervous system, a CDC discharge can be elicited by repetitive supra threshold depolarization of restingstate $\mathrm{CDCs}^{17}$ Egg-laying behaviour is a sequence of stereotyped movements in which three phases can be distinguished: resting, turning and oviposition. ${ }^{11}$ During turning, the animals make long-lasting turns of their shell through more than $60^{\circ}$ relative to the head-foot. These turns only occur in the second phase of egg-laying and are not part of the animal's other behavior patterns. ${ }^{18}$ It is to be expected, therefore, that the motor neurones involved in these shell movements will be inhibited during the resting phase and excited during the turning phase of egg-laying behavior. ${ }^{19}$ In Aplysia, it has been demonstrated that peptides released by the bag cells during and after discharge have a number of effects on the electrical activity of central neurons in vitro. ${ }^{20}$ These peptides also affect gill and siphon contractions and the 
arterial system. Injections of these peptides into intact animals also induce behavioral changes. ${ }^{13}$ An injection of $\mathrm{CDCH}$ (the ovulation hormone) induces egg-laying in Lymnaea although, following such injections, the animals do not show the first phase of egg-laying behaviour. ${ }^{14}$ Alpha $\mathrm{CDCP}$ and $\mathrm{CDCH}$ have an auto-excitatory function in Lymnaea. ${ }^{15}$ Until now; it has not been possible to study the role of the CDC peptides in regulating the neurones involved in overt egg-laying behaviour. With the identification of the nerves and motor neurones involved in turning behaviour during egg-laying in Lymnaea, we now have a neuronal model that may allow us to determine the effects of the peptides released by the caudodorsal cells during egg-laying. ${ }^{19}$ The central nervous system of the freshwater pulmonate snail Lymnaea stagnalis contains several neurosecretory cells which differ in histochemical and ultrastructural characteristics and are often found in groups which occur at characteristic locations in the ganglion ring. ${ }^{21}$ The axons of the neurosecretory cells run to the periphery of nerves, commissures or connectives where they terminate with many neurohaemal endings which release the products into the haemolymph by exocytosis. ${ }^{11}$ The caudo-dorsal cells (CDC), located in the cerebral ganglia, constitute one of these groups, and produce an ovulation hormone. ${ }^{22}$ Cells producing ovulation hormone are also known in opisthobranchs: the 'bag cells' of Aplysia which are usually electrically silent. ${ }^{23}$ The peptidergic Caudodorsal Cells (CDC) of the freshwater snail Lymnaea stagnalis control egg laying and egglaying behaviour by releasing various peptides that act upon different targets. ${ }^{22}$ Egg laying lasts about 2 hours and involves ovulation of up to 200 oocytes from the ovotestis, packaging of these cells by various types of female accessory sex gland into an egg mass, and oviposition. Kandel $^{24}$ argues that the bag cells of Aplysia have a 'triggering' function in the all or none act of egg-laying. Also usually silent, these cells can respond to strong electrical shock to the connectives with an after discharge in which all cells participate and during which the hormone is released. Vlieger et al., ${ }^{25}$ reported that a major factor determining the massive discharge of the bag cells is electrotonic coupling by 'remote' axonal processes. He also observed that in $L$. stagnalis electrotonic coupling appeared to be quite pronounced between all CDC and could very well explain that excitation in one cell spreads to all others, especially since in active cells there is a progressive increase in spike width, facilitating transmission across the junctions. Curti et al. ${ }^{26}$ reported that the importance of electrical coupling is underlined by the results on the morphology of the CDCs.

\section{Structure of the CDCs}

Roubos et al. ${ }^{27}$ reported that the CDC occur in two clusters in the cerebral ganglia (left: 25 cells, right: 75 cells). Each cluster contains 7 ventral CDC that have an axon branch running through the cerebral commissure. The "crossing axons" make electrotonic contacts with the contra lateral CDC, thereby enabling the cells of both clusters to function as one unit. ${ }^{28}$ Smirle et al. ${ }^{29}$ reported that the CDC are characterized by a well developed rough endoplasmic reticulum (RER) and Golgi apparatus and by electron-dense secretary granules with a mean diameter of about $150 \mathrm{~nm}$. Roubos et al. ${ }^{11}$ reported that the granule contents, including the ovulation-inducing peptide Caudodorsal Cell Hormone $(\mathrm{CDCH})$, are released into the haemolymph by exocytosis from neurohaemal axon terminals located in the periphery of the cerebral commissure. Furthermore, secretion occurs into the intercellular space of the central nervous system, from nonsynaptic release sites in the cerebral commissure.

\section{Role of dopamine}

Dopamine is commonly found in the molluscan central nervous system (CNS). In gastropods, dopamine has been implicated in the regulation of egg laying behaviour in L. stagnalis. ${ }^{18}$ Bislimi ${ }^{30}$ shown that the PVF secretion by the albumen gland could be stimulated by forskolin, cAMP, brain extract and dopamine. Dopaminergic neurons have been localized in the CNS of some snails such as L. stagnalis, Helix pomatia, Aplysia californica and Planorbis corneus, and they were mapped in the buccal ganglia of Helisoma trivolvis. Morgan ${ }^{31}$ showed that $3 \mathrm{H}$-dopamine accumulates specifically in the buccal, cerebral, pedal, left parietal and visceral ganglia, and the left pedal ganglion contains a greater amount of dopamine than the right. Kiehn et al. ${ }^{32}$ identified a giant dopaminergic neuron in the left pedal ganglion in the CNS of $H$. trivolvis containing neurons in the albumen gland and carrefour they neither specified the type of catecholamines nor their distribution within the albumen gland and the carrefour. Pena \& Edema $^{33}$ have shown that dopamine stimulates protein secretion from albumen gland. The albumen gland in pulmonate snails is an accessory gland of the female reproductive tract. It synthesizes and secretes perivitelline fluid (PVF), which is composed mainly of proteins and polysaccharides. Kiehn et al..$^{32}$ reported that mature oocytes are released by the ovotestis and travelvia the hermaphroditic duct into the carrefour, where the albumen gland duct empties. In the carrefour the eggs are fertilized and then are coated with the PVF. The importance of the PVF lies in the fact that it is a major nutrients source for the developing embryo since the oocytes themselves contain very little vitellogenic protein. Mukai ${ }^{34}$ reported that the secretion of the PVF and the arrival of oocytes at the carrefour must be synchronized, suggesting a precise control of the PVF release. Kiehn et al. ${ }^{32}$ identified a neuronal plexus in the duct of the albumen gland and the carrefour, which suggested that a nervous mechanism may be involved in the control of the PVF release. Furthermore, catecholamine-containing axons were identified in the albumen gland, carrefour and some other reproductive organs of $L$. stagnalis and other species of pulmonate snails. Bain et al. ${ }^{35}$ observed that overt egg laying behaviour consists of a number of stereotyped behavioural acts. It begins with cessation of locomotion and posture changes. After about one hour the animal starts crawling about and cleans the substrate by rasping with its buccal mass before depositing the egg capsule. Actual oviposition takes 10-20 minutes depending on the size of the egg mass. ${ }^{35}$ Finally, the animal crawls back along the egg mass, touching it with the lip, before moving off.

\section{Role of environmental factors}

Srivastava \& Singh ${ }^{18}$ noted that temperature increases beyond $33^{\circ} \mathrm{C}$ the reproductive rate decline. Sudden drops in temperature promote egg mass abortion. ${ }^{36} \mathrm{~A}$ temperature of $25^{\circ} \mathrm{C}$ is considered for optimal for oviposition and growth in pomacean snails $\mathrm{s}^{37}$ Earlier study has shown that decrease in temperature from $20^{\circ} \mathrm{C}$ to $8^{\circ} \mathrm{C}$ stopped the oviposition of snail Lymnaea stagnalis, because of reduction in activities of neurosecretory caudo dorsal cells (CDCs). ${ }^{38}$ Srivastava et al. ${ }^{10}$ reported that the fecundity, hatchability and survival of young snails show positive correlation with temperature. Seasonal fluctuations in the secretary neuro endocrine cells of Aplysia californica inhibited the protein Kinase $\mathrm{A}$ and $\mathrm{C}$ which play a significant role in regulation of egg laying hormone ${ }^{39}$ According to their cAMP and diacylglycerol second messenger pathways are regulated on a seasonal basis. ${ }^{40}$ Abiotic factors of the environment vary from one 
season to other. ${ }^{41}$ The aquatic environment has numerous physical and chemical parameters that may influence the physiology of fresh water organism. ${ }^{42}$ Embryological development is highly influenced by the change of ecological factors in aquatic environment. ${ }^{9}$ Ranjan ${ }^{43}$ stated that breeding season and the incubation period vary with the nature of the environment. Raut ${ }^{44}$ concluded that the rate of breeding in the number of snail's viz., Lymnaea acuminata, Indoplanorbis exustus and Acrostoma variabilis were governed by temperature, rainfall and food. Temperature negatively influenced the incubation period that means they reduced the incubation period and enhanced hatchability of snails. ${ }^{45}$ Possibly due to high temperature, low intake of oxygen concentration in water and increase in $\mathrm{CO}_{2}$ concentration and low $\mathrm{pH}$ of water. Seasonal variations were reported in mussel Camp contents ${ }^{46}$ were mainly observed in the mantle, reflecting a relationship with the gametogenesis cycle. ${ }^{47}$ Besides temperature, also other environmental and nutrition condition influence gametogenesis and spawning ${ }^{48}$ and a relationship with cAMP levels in the mantle was recently evidenced by Blanco et al. ${ }^{49}$ Indeed, high cAMP levels were found in autumn and winter, in parallel with lowest levels of ATP, ADP and AMP, possibly related to the activation of glycogen degradation to fuel gonadal development. ${ }^{48}$ The process of cellular growth and divisions requires the synthesis of nucleic acids and protein. Increase in $\mathrm{pH}$ from 7-8 caused a significant increase in DNA and protein level in ovotestis of $L$. acuminata. ${ }^{36}$ Dissolved oxygen is one of the most important ecological factors for survival of snail and other aquatic life. In general, most pond water can hold about 10 to $12 \mathrm{mg} / \mathrm{l}$ of oxygen. Temperature is one of the most important factor affecting dissolved oxygen levels. Oxygen dissolves easier in cold water than warm water. As temperature increases oxygen level decreases. Critically, low oxygen levels can occur during, hot summer months, when capacity is decreases due to high temperature and organism have a higher demand. In winter season water holds more oxygen than summer season. Different classes of gastropods show variation in oxygen consumption such as prosobranch and pulmonate snails have similar levels of oxygen consumption whereas, ophisthobranch snails have higher oxygen consumption. Lymnaea is very sensitive to dissolved oxygen content of water. It has been reported that fecundity in some animal does not respond to higher oxygen. It has also been reported that dissolved oxygen below $20 \%$ saturation causes stress to fresh water muscles. High oxygen concentration changes the chemical composition of water as well as morphological characteristics of caudo dorsal cells (CDCS) and physiology of snails. ${ }^{40}$ Dissolved oxygen increased the incubation period and the hatchability through incomplete or slow development of the embryo. These hydrogen ions determine the acidity of the aquatic body, accounting the change in $\mathrm{pH}$. Carbon dioxide decreases the $\mathrm{pH}$ of water because of increase in concentration of $\mathrm{H}+$. The direct effect of high $\mathrm{CO}_{2}$ exposure can be reduction in metabolism, protein synthesis, growth rate and reproduction in marine animals. ${ }^{50}$

\section{Role of AChE enzyme}

Srivastava et al. ${ }^{10}$ reported that a significant positive correlation between the AChE activity and the fecundity of snail. The enzyme is responsible for the breakdown of ACh in cholinergic synapses, preventing continuous nerve firing, which is vital for normal cellular neurotransmitter functioning. ${ }^{48}$ It indicates that the reproductive capacity of snail up to some extent is mediated through cholinergic stimuli in the brain of snail. Singh et al. ${ }^{51}$ reported that prostaglandins have significant role in the egg laying of snail L. acuminata and after treatment with molluscicides it inhibit the prostaglandins metabolism in exposed snail. The AChE inhibition result in accumulation of acetylcholinesterase at the nerve synapses so that the post synaptic membrane is in a state of permanent stimulation producing paralysis, ataxia and general lack of coordination in neuromuscular system and eventual death of the snails.

\section{Conclusion}

Present review summarizes that the how egg laying affected by abiotic factors and functioning of the neural cell enzymes. Because Molluscs are still used extensively as model species for neuroendocrine processes that regulate different types of behaviors. Regulation of egg laying behaviors for understanding the evolution of hermaphroditic mode of reproduction.

\section{Acknowledgements}

None.

\section{Conflict of interest}

There are no financial conflicts of interest to report.

\section{References}

1. Kocot KM, Halanych KM, Krug PJ. Phylogenomics supports Pulmonata: Opisthobranch paraphyly and key evolutionary steps in a major radiation of gastropod mollusks. Mol Phylogenet Evol. 2013;69(3):764-771

2. Singh DK, Singh VK, Kumar P. editors. Pestiferous gastropods and their control. Germany: LAP Lambert, Academic Publication GmbH and $\mathrm{Co}$; 2012:1-152.

3. ZSI. Snails, Flukes and Man. India: Zoological Survey of India; 1991. pp. $1-113$.

4. Brown DS, Curtis BS, Bethune S. Freshwater snails of east Caprivi and the lower Okavango river basin in Namibia and Botswana. Hydrobiologia. 1992;246(1):9-40.

5. Duncan CJ. Reproduction in pulmonates. In: Fretter V, Peake JF, editors, Pulmonates. New York: Academic Press; 1975:309-365.

6. Geraerts WPM, Joosse J. Freshwater snails (Basommatophora). In: Tompa AS, Verdonk NH, van den Biggelaar JAM, editors. The Mollusca Reproduction. New York: Academic Press; 1984:142-207.

7. Chase R. Gastropod reproductive behavior. Scholarpedia. 2007;2(9):4125.

8. Colton H. Some effects of environment on the growth of Lymnaea columella Say. Proc Acid Nut Sci. 1908;60(3):410-448.

9. Jigyashu HV, Singh VK. Effect of environmental factor on the fecundity, hatchability and survival of the snail Lymnaea acuminata (Lamark): vector of fascioliasis. J Water Health. 2010;8(1):109-115.

10. Srivastava AK, Singh DK, Singh VK. Abiotic factors and antireproductive action of bait containing eugenol against Lymnaea acuminata. Scient J of Biolog Sci. 2013;2(4):76-85.

11. Roubos EW, Jenks BG, Xu L, et al. About a snail, a toad, and rodents: animal models for adaptation research. Front Endocrinol(Lausanne). 2010;1:4.

12. Ferguson GP, Pieneman AW, Jansen RF, et al. Neuronal feedback in 
egg-laying behaviour of the pond snail Lymnaea stagnalis. J Exp Biol. 1993;178:251-259.

13. Hermann PM, Maat AT, Jansen RF. The neural control of egg-laying behaviour in the pond snail Lymnaea stagnalis: motor control of shell turning. J Exp Biol. 1994;197(1):79-99.

14. Koene JM. Neuro-endocrine control of reproduction in hermaphroditic freshwater snails: mechanisms and evolution. Front Behav Neurosci. 2010;4:167

15. Hermann PM, Delange RPJ, Pieneman AW, et al. Role of neuropeptides encoded on $\mathrm{CDCH}-1$ gene in the organization of egglaying behavior in the pond snail, Lymnaea stagnalis. J Neurophysiol. 1997;78(6):2859-2869.

16. Brussaard AB, Schluter NCM, Ebberink RHM, et al. Discharge induction in molluscan peptidergic cells requires a specific set of auto excitatory neuropeptides. Neuroscience. 1990;39(2):479-491.

17. Hordijk PL, Brink MJ, Maat AT, et al. The neuropeptide schistosomin and haemolymph from parasitized snails induce similar changes in excitability in neuroendocrine cells controlling reproduction and growth in a freshwater snail. Neurosci Lett. 1992;136(2):193-197.

18. Srivastava AK, Singh VK. Reproductive behaviour of snail Lymnaea acuminata. Micro Medicine. 2015;3(1):8-19.

19. Benjamin PR. Lymnaea. Scholarpedia. 2008;3(1):4124.

20. Sun B, Tsai PS. A gonadotropin-releasing hormone-like molecule modulates the activity of diverse central neurons in a gastropod mollusk, Aplysia californica. Front Endocrinol(Lausanne). 2011;2:36

21. Kanapala VK, Arasada ASP. Histology and cytochemistry of the neurosecretory cells (NSC) of the freshwater snail Lymnaea luteola (Lamarck) Mollusca: Gastropoda. Int $J$ of Zool Res. 2015;11(5):215-221.

22. Jimenez CR, Maat AT, Pieneman A, et al. Spatio-temporal dynamics of the egg-laying-inducing peptides during an egg-laying cycle: a semi quantitative matrix-assisted laser desorption/ionization mass spectrometry approach. J Neurochem. 2010;89:865-875.

23. Chase R. editor. Behavior and its neural control in gastropod molluscs. New York: Oxford University Press; 2002:1-336.

24. Kandel ER. Cellular Basis of Behavior. San Francisco: WH Freeman and Company. 1976

25. Vlieger TAD, Kits KS, Maat AT, et al. Morphology and electrophysiology of the ovulation hormone producing neuroendocrine cells of the freshwater snail Lymnaea stagnalis (L.). J Exp Biol. 1980;84:259-217.

26. Curti S, Hoge G, Nagy JI, et al. Synergy between electrical coupling and membrane properties promotes strong synchronization of neurons of the mesencephalic trigeminal nucleus. $J$ Neurosci. 2012;32(13):4341-4359.

27. Roubos EW, Van De Ven AMH. Morphology of neurosecretory cells in Basommatophoran snails homologous with egg-laying and growth-hormone producing cells of Lymnaea stagnalis. Gen Comp Endocrinol. 1987;67(1):7-23.

28. Roubos EW. Cytobiology of the ovulation-neurohormone producing neuroendocrine caudo-dorsal cells of Lymnaea stagnalis. Int Rev Cytol. 1984;89:295-346.

29. Smirle J, Catherine EA, Jain M, et al. Cell biology of the endoplasmic reticulum and the golgi apparatus through proteomics. Cold Spring Harb Perspect Biol. 2013;5(1):a015073.
30. Bislimi K, Behluli A, Halili J, et al. Impact of pollution from Kosova'S power plant in obiliq on some biochemical parameters of the local population of Garden Snail (Helix Pomatia L.). Resources and Environment. 2013;3(2):15-19.

31. Morgan LD. A characterization and functional analysis of the role of the 14-3-3- like protein in neural ageing in pond snail Lymnaea stagnalis. A thesis submitted in part fulfillment of the requirements of the University of Brighton for the degree of Doctor of Philosophy. UK: The University of Brighton. 2012. p.1-286.

32. Kiehn L, Saleuddin S, Lange A. Dopaminergic neurons in the brain and dopaminergic innervations of the albumen gland in mated and virgin Helisoma duryi (mollusca: pulmonata). BMC Physiol. 2001;1:9.

33. Pena JJ, Adema CM. The planorbid snail biomphalaria glabrata expresses a hemocyanin-like sequence in the albumen gland. PLoS ONE. 2016;11(12):e 0168665.

34. Mukai ST. Involvement of the endocrine dorsal bodies and the central nervous system in the physiology of reproduction in Helisoma duryie (Mollusca Pulmonata). A thesis submitted to the Faculty of Graduate Studies in partial fulfilment of the requirement for the degree of Doctor of Philosophy Graduate programme in Biology York University Toronto, Ontario. 1998. p.1-325.

35. Bain MM, Nys Y, Dunn IC. Increasing persistency in lay and stabilizing egg quality in longer laying cycles. What are the challenges? British Poultry Science. 2016;57(3):330-338.

36. Jigyshu HV, Singh DK, Singh VK. The effect of abiotic factors on certain biochemical changes in ovotestis of snail Lymnaea acuminata: Intermediate host of trematode diseases. Global Veteranaria. 2010;4(5):521-523.

37. Srivastava AK. Effect of certain attractant bait formulations, containing plant molluscicides on the reproduction of Lymnaea acuminata with reference to seasonal variation in abiotic factors. Ph.D. Thesis, DDU Gorakhpur University, Gorakhpur, India, 2013.

38. Pande GG, Patil MU, Prabhakar UD, et al. Effect of photoperiod and temp on egg laying activity of fresh water pulmonate snail Lymnaea acuminata (Lamark, 1822) (Gastropoda: Mollusca) kept under laboratory breeding conditions. Bioscan. 2009;4(4):717-720.

39. Wayne NL, Kim YJ, Yong-Montenegro RJ. Seasonal fluctuations in the secretary response of neuroendocrine cells of Aplysia californicato inhibitors of protein kinase A and protein kinase C. General Comp Endocrinol. 1998;109(3):356-365.

40. Srivastava AK, Singh DK, Singh VK. Influence of abiotic factors on anti-reproductive activity of bait containing papain in Lymnaea acuminata. Annu Res Rev Biol. 2014;4(1):223-237.

41. Agrahari P, Singh VK, Singh DK. Toxicity of snail attractant pellets containing eugenol with respect to abiotic factors against the vector snail Lymnaea acuminata. Biological Agriculture \& Horticulture. 2012;28(3):156-166

42. Grosberg RK, Vermeij GJ, Wainwright PC. Biodiversity in water and on land. Curr Biol. 2012;22(21):R900-903.

43. Ranjan AR. The embryology of the apple snail Pila globosa (Swanion) (Mollusca: Gastropoda). Rec Ind Mus. 1942;44:217-322.

44. Rout SK. Population interaction among fresh water snails. Proc Symp Ecol Anim Popul. 1981;2:163-173.

45. Sarker MM, Nesa B, Jahan MS. Embryonic development ecology of fresh water snail Lymnaea acuminata (Lymnaeidae; Gastropoda). Pak J Biol Sci. 2007;10(1):23-31. 
46. Dailianis S, Domoutsidou GP, Raftopoulou E, et al. Evaluation of neutral red retention assay, micronucleus test, acetylcholinesterase activity and a signal transduction molecule (cAMP) in tissues of Mytilus galloprovincialis (L.), in pollution monitoring. Mar Environ Res. 2003;56(4):443-470.

47. Diaz-Enrich MJ, Ibarguren I. Implication of adenosine 3,5-cyclic monophosphate, guanosine 3,5-cyclic monophosphate, adenosine3,5-mono-, di-, and triphosphate and fructose-2,6-bisphosphate in the regulation of the glycolytic pathway in relation to the gametogenic cycle in the mussel Mytilus galloprovincialis Lmk. Mol Cell Biochem. 2003;252(1-2):339-345.

48. Fabbri E, Capuzzo A. Cyclic AMP signaling in bivalve mollusks: An overview. J Exp Zool A Ecol Genet Physiol. 2010;313(4):179-200.
49. Blanco SL, Suarez MP, San Juan F. Seasonal changes of nucleotides in mussel (Mytilus galloprovincialis) mantle tissue. Comp Biochem Physiol. 2006;143(3):384-390.

50. Soetan KO, Olaiya CO, Oyewole OE. The importance of mineral elements for humans, domestic animals and plants: A review. African Journal of Food Science. 2010;4(5):200-222.

51. Singh RN, Kumar P, Singh VK, et al. Toxic effects of deltamethrin on the levels of biochemical changes in the snail Lymnaea acuminata. $J$ Pharma Res. 2010;3(8):1739-1742. 